\title{
Gender and Self in Children's Autobiographical Narratives
}

\author{
JANINE P. BUCKNER* and ROBYN FIVUSH \\ Emory University, USA
}

\begin{abstract}
SUMMARY
In this study, we examined relations among gender, self-concept and children's autobiographical narratives. Twenty-two white middle-class children 8 years of age (50\% female) were administered the Children's Self-View Questionnaire (CSVQ). In addition, children were asked to recall a specific experience associated with each of the nine self-concept dimensions assessed by the CSVQ, including Achievement, Alienation, and Social Closeness. Consistent with previous research with adults, girl's autobiographical narratives were longer, more coherent and more detailed than were boys' narratives. Girls were also more likely to place their autobiographical narratives in a social context, to refer to more affiliative themes, and to mention more people and more emotions than were boys. In all these ways, girls' narratives were more socially contexted and relational than were those of boys. However, no relations were found between specific dimensions of self-understanding and children's autobiographical narratives. Theoretical implications of these findings are discussed. (C) 1998 John Wiley \& Sons, Ltd.
\end{abstract}

Appl. Cognit. Psychol. 12: 407-429 (1998)

Autobiographical memory is the recollection of facts and events that have been interpreted and integrated into a consistent story about one's self (Bruner, 1987; Neisser, 1988). In reminiscing, we often focus on the defining moments which have shaped our lives. From this activity we construe a sense of identity (Bannister and Agnew, 1976; Fivush, 1993a; Spence, 1982). Recent research with adults suggests that current self-concept is not only enhanced by personal memory but may in fact play an active role in organizing and interpreting past experience (Barclay and Subramanian, 1987; Markus, 1977, 1982; Neimeyer and Rareshide, 1991). Our beliefs about the kinds of people we are influence the kinds of stories we include in our life autobiographies, and impact the specific manner in which we relate them to others. Developmental theorists support this contention as well (Damon and Hart, 1988; Eder et al., 1987; Harter, 1988). To date, however, little research has examined developing relations between self-concept and autobiographical memory. The purpose of this study, therefore, was to begin to address how individual differences related to current self-concept might influence children's recall of their personal past.

According to a cognitive perspective of the self, 'habitual patterns of thought determine the way in which the individual focuses attention on information or

*Correspondence to Janine P. Buckner, Department of Psychology, Emory University, Atlanta, GA 30322, USA. E-mail: janine@social-sci.ss.emory.edu 
remembers events' (Leahy, 1985, p. 271). In Markus' (1977, 1983) theorizing, the self consists of a set of cognitive-affective knowledge structures or categories (schemes) which mediate all aspects of behaviour. These schemes are used to process and interpret self-relevant events in order to make experience meaningful (Barclay, 1986; Bruner, 1987; Leahy and Shirk, 1985; Markus and Nurius, 1987; Oyserman and Markus, 1993; see also Greenwald, 1980).

One of the most salient components of identity is gender. The extent to which we define ourselves as female or male plays an enormous role in how we view the world. Much research has demonstrated that gender stereotypes guide perception and memory, and exert a powerful influence on the kinds of personalities we attribute to others, and to ourselves (Bem, 1981; Herrmann et al., 1992; Huston, 1988; Liben and Signorella, 1980). Moreover, a great deal of research indicates that males and females are socialized into different interpersonal orientations; whereas females are encouraged to be nurturant and socially connected, males are encouraged to be independent and autonomous (see Golombok and Fivush, 1994, for a review, but see Lytton and Romney, 1991 for a different view). These early socialization differences may build upon biological dispositions towards particular social orientations relating to nurturance and aggression (Ehrhardt et al., 1984; Urdry, 1994).

In line with these gender-related interpersonal orientations, Gilligan (1992) has observed that adolescent and adult males and females employ distinct cognitive styles, representing feminine and masculine 'voices'. According to Gilligan, females' voices are centred around belongingness, interdependence within a social network, and a moral responsibility to care about others. Organized around the ability to make and maintain relationships, females typically devalue aggression towards other people, and express a responsibility to maintain order in a well-connected social life. Quite different from this perspective, males' voices are highlighted by special accomplishments and skills that make them distinct, or set apart from the world. Whereas the female selfconcept tends to focus on intimacy and cohesion, separation defines the male identity. In fact, Gilligan reports that even when males do refer to others, it is usually within the context of an individual success story. Such differences between 'autonomous' and 'connected' styles have been supported in many other domains, ranging from the cognitive processing of visual information (Meyers-Levy, 1989) to social-emotional communication styles (Markus and Oyserman, 1989). In fact, gender differences in these social-cognitive orientations have been observed early in development in children's play (Lever, 1976; Sheldon, 1990), story narratives (Nicopoulou et al., 1994), and communication styles (Leaper, 1991; Tannen, 1990).

Gender schema inform not only present attributions and thoughts about the self but also our remembrance of the personal past. For example, many studies document that females reminisce more vividly, and more often than males (Fitzgerald and Lawrence, 1984; Holmberg and Veroff, 1991; Ross and Holmberg, 1990). Moreover, females report remembering for more social reasons. For instance, females often report that they reminisce with others for the sake of conversation, to remember a deceased loved one, or to increase intimacy with a significant other (Bischoping, 1993; deVries et al., 1982). Males, on the other hand, prefer to reminisce about events in which they were successful, or for the sake of political discussion (Merriam and Cross, 1982).

Consistent with the connectivity/autonomy distinction between females' and males' cognitive styles, relations with others appear to be the basic elements in females' 
narratives about their personal past (Adcock and Ross, 1983; Belenky et al., 1986; Cowan and Davidson, 1984; Schwartz, 1984; Thorne, 1995). In their memories of both childhood and more recent past experiences, adult females typically focus their narratives on affiliative themes; they talk about their roles in relationships, the importance of other people in their lives, and the struggles they experienced when intimacy was threatened or denied. Females' earliest memories are typically about sibling rivalry, childhood playmates, or being misunderstood by parents (Schwartz, 1984). Quite differently, a majority of males' autobiographical memories focus on experiences relating approval or praise from others, or themes of youthful recreation (Schwartz, 1984; Thorne, 1995). They report more memories about mastery and performance, and people who positively influenced them to succeed. Thus males appear to remember best those experiences in which they achieved a goal, fulfilled a desire, or in some other way were self-satisfied (Cowan and Davidson, 1984; Sehulster, 1996). While the inclusion of other people in their descriptions of the past is characteristic of females' narratives, males' memories have a noticeable lack of details about other people. On this basis, males' memories of personal experiences have generally been characterized as separate, independent, or egocentric, whereas females' narratives are typically labeled as connected or interdependent (Oyserman and Markus, 1993; Huston, 1988).

It is important to stress that these findings do not imply that men do not care about other people, or that women are not achievement-oriented. Rather, men and women appear to be motivated to remember different aspects of their experiences. For men, the goal is to be unique, to de-identify from others, to be separate; the themes expressed by women however suggest that they want to be connected (Tannen, 1994). Thorne's (1995) data are an excellent case in point. Thorne asked adults to recount memories of various time points in their lives, from early childhood to the present. Prevalent in adult males' memories about childhood were desires to avoid others, particularly parents, which is suggestive of a budding sense of independence. Although both males and females expressed a majority of memories about wanting love, seeking approval, and needing help, females had higher frequencies than men in these categories. Of particular interest is the distribution of memories about needing help from others, presumably an index of autonomy. A decrease in need of help occurred in males' memories over time into the present; in females, too, a decrease occurred but only until early adolescence, at which time it began to rise again. Other differences were also present in the frequency of memories about other people; whereas females included parents more often than men across most remembered age periods, males reported more memories about teachers and employers, people closely related to achievement and individual success stories. Beginning in adolescence, Stapley and Haviland (1989) found that boys, like their adult counterparts, embedded their stories of the past in situations focused on autonomy and activity, while girls more often highlighted affiliative aspects of experience, such as who else was involved in the events.

But it is not just the content of what females and males report about the past that differs; females also organize their personal narratives differently from males. Females' personal narratives are longer, contain more detail, and are generally judged by both males and females as more accurate than males' (deVries et al., 1995; Friedman and Pines, 1991; Ross and Holmberg, 1990; Yarmey, 1993). As early as the preschool years, there is also some evidence that girls report longer, more temporally 
complex, and more evaluative personal narratives than do male peers (Fivush et al., 1995).

These findings suggest that gender differences in autobiographical memory may emerge early in development and may be part of children's evolving understanding of self. One of the major objectives of this study was to investigate more systematically possible gender differences in young children's autobiographical memories, in terms of both structure and content. Based on the limited developmental research, we expected girls would report longer, more temporally and causally complex, and more richly detailed narratives. Furthermore, we predicted that girls' narratives would be more socially oriented than those of boys. Girls' narratives were expected to incorporate more affiliative themes, and mention more people and relationships than those of boys. These results would be in line with current thinking that males build an identity by what makes them unique, while females' identity is formed by the web of connections that are established and maintained in their lives (Belenky et al., 1986; Cowan and Davidson, 1984; Gilligan, 1992; Tannen, 1990).

Of course, there is wide variability within gender groups as well as between females and males. Thus, a second objective of this research was to examine how specific individual differences in self-knowledge might be related to differences in autobiographical memories. Along any given trait or dimension of personality, some people evolve well-defined or 'articulated' schemas for the self. Others may not view particular dimensions as important or valuable, and therefore not have wellarticulated structures for such knowledge. According to Markus (1977) those schemas which are valued as meaningful to identity will be the most articulated or elaborate. Other schemes remain peripheral aspects of identity. Thus, Markus distinguishes between individuals who are 'schematic' on a particular dimension, i.e. who have a strong commitment to that dimension of self-understanding, and individuals who are 'aschematic' on that domain, i.e. who do not particularly subscribe to a given dimension of personality.

Markus (1977) posited that individuals schematic for a given domain of knowledge have an advantage over aschematics when processing schema-relevant information. Based on findings for the self-reference effect (see Rogers et al., 1977 for a review), Markus theorized that individuals schematic for a dimension assimilate schemarelevant information more efficiently and elaboratively, in part because relevant structures are already organized in their memories. As a consequence, since schemas are reflections of past behaviour, schematics would have more behavioural evidence (memories) to support schema-relevant information. Thus, individuals schematic for a trait, such as dependence, would provide more memories for words relating to dependence in comparison to people 'aschematic' for that dimension. Research confirmed Markus' predictions (Markus, 1977, 1982). On the basis of such findings Markus concluded that personal memories appear to be encoded and recalled in relation to an existing self-structure (see also Barclay, 1986).

Other research supports this notion of enhanced processing for information related to schematic domains of self-knowledge (Barclay and Subramanian, 1987; Markus, 1977, 1982; Neimeyer and Rareshide, 1991; Orlofsky and Frank, 1986). For example, based on Marcia's (1966) model of identity formation, Neimeyer and Rareshide (1991) found that adolescents with more developmentally advanced identity statuses (more committed, fewer crises) reported more personal memories in support of words judged to be self-descriptive than did individuals with less 
advanced statuses. They concluded that at more advanced stages of identity development there is greater complexity, richer definition, and higher organization of selfknowledge which in turn guides and supports personal memory recall.

Although such evidence supports the link between self-concept and autobiographical memory among adolescents and adults, there is almost no research on the development of this relationship in children. Developmental theorists have generally characterized the progression of self-understanding in children as a gradual shift. Early on, self-conceptualization is mainly based on physical characteristics such as hair colour, body size, or clothing; but as children mature into middle childhood, they develop a sense of identity constancy based on more abstracted notions of self, such as psychological traits (Damon and Hart, 1988; Eder, 1989; Eder et al., 1987; Harter, 1983, 1988). However, no work has explored the ways in which this developing selfconcept is expressed through children's understanding of personally relevant experiences.

In this study we were particularly interested in whether the level of schematicity of self-knowledge would affect recall. Markus (1977, 1982), Neimeyer and Rareshide (1991), and Barclay and Subramanian (1987) suggest that information which is relevant to elaborated aspects of self-concept are more quickly processed and are more coherently organized. We therefore expected that the structure of children's autobiographical memories about schematic dimensions would be different from memories about dimensions not schematized. Specifically, it was predicted that narratives about dimensions on which children were judged to be schematic would be more coherent, more detailed, and organized than those about aschematic dimensions. It was not clear how schematicity would influence the interpersonal content of narratives, but we did expect to find differences in emotionality. Since emotional details are assumed to mark the personal significance of an experience (Fivush, 1993a; Labov, 1982), we expected narratives about schematic dimensions to contain more emotion talk than narratives about aschematic dimensions of self-concept.

In summary, in this research we examined relations between children's selfunderstanding and their autobiographical narratives. We expected both the structure and content of children's narratives of personally meaningful experiences to vary as a function of gender and individual differences in specific dimensions of self-definition.

\section{METHOD}

\section{Participants}

Participants in this study were 22 white middle-class children ( $50 \%$ female), about $71 / 2$ years of age (range 90-94 months) who were recruited through the Emory Child Database. All parents had some college education. Children were recruited in one of two phases in the study. About half of the children ( 8 girls, 6 boys) were involved in a larger longitudinal study of autobiographical memory; in total, these children were visited at five time points, just after their third birthday, and just before their fourth, fifth, sixth, and eighth birthdays (mean ages, 36, 46, 58, 70, and 94 months respectively). Data relevant to this paper were collected during a single visit in the final phase of this project. In addition, data were collected from a second set of age-matched participants ( 3 girls, 5 boys) after the final phase of the original study was completed. However, all visits and tasks were identical in nature. 


\section{Procedure}

Participants completed two separate tasks during a single home visit by an experimenter and an assistant. One task was a self-concept scale (the Children's Self-View Questionnaire) designed by Eder (1990), and the other an autobiographical memory task related to Eder's self-concept dimensions. The order of these tasks was counterbalanced across children. ${ }^{1}$

\section{Measures}

\section{The Children's Self-View Questionnaire (CSVQ)}

Eder's scale is a 55-item forced-choice recognition test administered by two persons. The 55 items comprising the scale consist of pairs of statements, which when scored divide into nine subscores corresponding to nine a priori psychological dimensions of self-concept, as defined by Eder (1990) and Tellegen (1985, as discussed in Eder, 1990). Each pair of statements reflects the low and high ends of the dimensions of Achievement, Aggression, Alienation, Harm-Avoidance, Social-Closeness, SocialPotency, Stress-Reaction, Traditionalism, and Well Being (Eder, 1990). ${ }^{2}$ Examples of statement pairs related to each dimension are listed in Table 1.

The CSVQ (1990) is administered with participants sitting across from the experimenters who are in full view. The interview is conducted using two horse puppets who are introduced to male subjects as 'Ben and Kurt', and to female subjects as 'Beth and Kate'. Each of the 55 statement-pairs are spoken by the puppets in a fixed order such that no puppet speaks first more than two consecutive times. High and low ends of each dimension are also randomly assigned to puppets. For the administration of the task, one experimenter operates both puppets, while the other records subject responses.

Children were introduced to the puppets by an experimenter saying 'These two puppets are writing a story about kids your age. They want to learn all about you. They are going to tell you about themselves, and then you tell them about yourself. Are you ready?' Children were then given two sets of practice statements on which the experimenters provided general encouragement ('That was great!! You've got the idea!'). As each puppet made a statement, the child was asked by the non-puppeteer to listen to and pick one statement that was most like herself. Children were encouraged to give verbal responses to the puppets and not to point. Following the practice items, the 55 pairs of statements were given and children's responses were recorded.

\footnotetext{
${ }^{1}$ Children in the longitudinal study were administered the self-concept scale when they were 5,6 , and $71 / 2$, but only the most recent scores were relevant to the present investigation. Memory narratives were, however, only obtained at the last time point. Although children were observed in several narrative situations involving autobiographical memory interviews during the entire length of the longitudinal study, the narrative task related to self-concept in the final time point was designed in a particular manner. More specifically, this task elicited narratives specific to the dimensions of self-concept described below. For participants in the longitudinal study, both tasks were counterbalanced with other tasks across a series of four visits to participants' homes.

${ }^{2} \mathrm{~A}$ revised version of the scale is available which consists of 62 items, and measures a tenth dimension, Social Anxiety. At the first time point in this study, however, the revised version was not available. Although the revised edition was available for the later time points, the original version was used for the remainder of the study.
} 
Table 1. Dimensions of self-concept, sample CSVQ items, and associated narrative prompts used to elicit self-concept narratives

\begin{tabular}{|c|c|c|}
\hline Dimension & Sample statement pairs from CSVQ & Narrative prompt \\
\hline Achievement & $\begin{array}{l}\text { A. I don't care if I don't do a really } \\
\text { good job on everything that I do. } \\
\text { B. I care about doing a really good job } \\
\text { on everything I do. }\end{array}$ & $\begin{array}{l}\text { Tell me about a time when you } \\
\text { worked really hard at something } \\
\text { because you wanted it to come } \\
\text { out really good. }\end{array}$ \\
\hline Aggression & $\begin{array}{l}\text { A. When I get angry, I feel like being } \\
\text { quiet. } \\
\text { B. When I get angry, I feel like hitting } \\
\text { someone. }\end{array}$ & $\begin{array}{l}\text { Tell me about a time you tried to } \\
\text { hurt somebody or tried to scare } \\
\text { them. }\end{array}$ \\
\hline Alienation & $\begin{array}{l}\text { A. People don't like me. } \\
\text { B. People like me. }\end{array}$ & $\begin{array}{l}\text { Tell me about a time when you } \\
\text { felt left out, all alone, or that } \\
\text { nobody cared about you. }\end{array}$ \\
\hline Harm & A. When I am scared, I run away. & Tell me about a time when you \\
\hline Avoidance & $\begin{array}{l}\text { B. When I am scared, I stand up to } \\
\text { what scares me. }\end{array}$ & $\begin{array}{l}\text { didn't do something because you } \\
\text { were afraid you would get hurt. }\end{array}$ \\
\hline Social Closeness & $\begin{array}{l}\text { A. I am happiest when I'm around } \\
\text { people. } \\
\text { B. I am happiest when I'm by myself. }\end{array}$ & $\begin{array}{l}\text { Tell me about a time when you } \\
\text { had fun just because you were } \\
\text { with someone. }\end{array}$ \\
\hline Social Potency & $\begin{array}{l}\text { A. I pick the game to play. } \\
\text { B. Other people pick the game to play. }\end{array}$ & $\begin{array}{l}\text { Tell me about a time that you } \\
\text { were the leader or when you } \\
\text { were in charge of everybody. }\end{array}$ \\
\hline Stress Reaction & $\begin{array}{l}\text { A. A lot of things make me upset. } \\
\text { B. It is hard for me to get upset. }\end{array}$ & $\begin{array}{l}\text { Tell me about a time when you } \\
\text { were scared, upset, or angry. }\end{array}$ \\
\hline Traditionalism & $\begin{array}{l}\text { A. I sometimes do things that I'm not } \\
\text { supposed to do. } \\
\text { B. I never do things that I'm not } \\
\text { supposed to do. }\end{array}$ & $\begin{array}{l}\text { Tell me about a time when you } \\
\text { behaved really politely or had } \\
\text { good manners. }\end{array}$ \\
\hline Well Being & $\begin{array}{l}\text { A. I laugh a lot. } \\
\text { B. I don't laugh a lot. }\end{array}$ & $\begin{array}{l}\text { Tell me about a time when you } \\
\text { were happy or silly. }\end{array}$ \\
\hline
\end{tabular}

\section{Narrative memory task}

The narrative task was a prompted recall interview in which children were asked to recall a specific experience related to each of the nine dimensions measured on the CSVQ (1990). The nine prompt statements used to elicit narratives directly corresponded to descriptions of each dimension outlined in Eder (1990), since they were based on specific items included in the CSVQ. Each prompt began with 'Tell me about a time when ...' (for example, 'Tell me about a time when you were the leader or when you were in charge of everyone'). The prompts are listed in Table 1. To randomize the order of prompts across children, each statement was typed on a $3 \times 5$ inch index card, and shuffled before presentation to children. Children were instructed to pick one card from the set of nine, and then asked to read the card aloud. Each child was then encouraged to report a memory that related to one time that the situation described occurred. ${ }^{3}$

\footnotetext{
${ }^{3}$ In order to ensure that all subjects understood the statements regardless of reading ability, the experimenter repeated the statement if it was read with difficulty by the subject.
} 
The task began with a neutral practice item that was not related to any of the dimensions outlined by Eder (1990). It was used to demonstrate the structure of the task. Specifically, children were instructed as follows:

I am interested in what kids remember about things they did some time ago, and I would like to play a game with you. On these cards are sentences describing some things that may have happened to you. I'm going to hold them out to you and then ask you to pick one. After you pick a card, I'll ask you to read the sentence and tell me about one time when something like this happened to you. For example, say you picked a card that said 'Tell me about a time when you ate something you didn't like.' What I would like you to do is think really hard about it and tell me about one specific time when you ate something that you didn't like. Okay? Let's try the example. Tell me about a time when you ate something you didn't like.

Subjects were then asked to provide an example for this practice item, when they ate something they didn't like. They were encouraged to tell about the event with neutral prompts ('Tell me about that' or 'Anything else?') until they said 'that's all' or there was nothing else they wished to say. If a child was not specific (reporting a general occurrence) experimenters followed up with encouragement, 'That's good, but can you tell me about one specific time when you ate something you didn't like?' Experimenters repeated the procedure for follow-up prompts until a narrative was given, or a subject refused to respond with a specific occasion. Throughout this task experimenters gave only non-directive prompts, such as 'What else?' or 'What happened next, after that?', or 'Tell me more about that'. After children did the practice item, they were asked to do the same for the nine narrative items typed on index cards. This narrative task was audiotaped for transcription and coding.

After the interview, mothers were asked to corroborate the occurrence of each event. Of these narratives, 94\% were corroborated, in the sense that mothers agreed the event occurred. In the remaining cases, mothers indicated that these events happened outside of their own experiences with their children (in school or elsewhere). It should be noted that the content of what children recalled was not subjected to confirmation. However, the main objective of this study was to examine how children understand and narrate their experiences, and not how accurate the details of their memory were. Still, given previous research indicating high accuracy in free recall of past experiences with children this age and even younger (see Fivush, 1993b for a review), we can assume that children's reports were reasonably accurate.

\section{Narrative coding}

Transcripts from the narrative interview session were transcribed verbatim and coded for both structure and content. Only specific narratives were coded, where a specific narrative was defined as one pertaining to a particular episode defined in time. In cases where subjects responded with more than one specific episode, only the first narrative was coded. The coding schemes used in the present study were adapted from previous coding schemes used in the literature (see Peterson, 1994, for discussion and review), and through inspection of protocols as coding reliability was established. 


\section{Narrative structure}

Structure refers to the level of elaboration and coherence of a narrative. More highly structured narratives are assumed to reflect more organized and more articulated autobiographical memories. Level of narrative elaboration was determined by the following two measures:

I. The number of clauses within a narrative, where a clause is a proposition which includes a subject and predicate. Only clauses containing new information were counted. Length of narrative is thus a measure of how elaborated the narrative is.

II. Descriptive detail: Adjectives and adverbs were counted for each narrative. Number of descriptive details are a measure of how richly embellished the narrative is.

Level of narrative coherence was determined by the frequency of temporal and causal terms, and story structure.

III. Temporal/causal terms: Markers of narrative order were tabulated, both temporal sequence markers (e.g. after that, then, next, first) and terms indicating causal sequence (e.g. if, because, so). Use of these kinds of words indicates more sequentially organized narratives.

IV. Story structure was based on a 0-to-3 rating of overall structure and organization. These ratings were adapted from Peterson's (1994) classification of structure:

3-(Classic pattern): Narrative builds to a high point, evaluatively dwells on it, then resolves it.

2-(Ending-at-the-high-point): Narrative builds to a high point, then ends; there is no 'wrap up' or resolution.

1-(Chronological pattern): Narrative describes successive events that are sequentially and logically ordered.

0 -(Disoriented pattern): Narrative is too confused, disoriented, or contradictory for the listener to understand.

\section{Narrative content}

Content refers to the themes and the social orientation of the narratives.

I. Overall theme: Each narrative was coded as being solely about the child and his or her own experience (an Individual narrative, e.g. a child's memory of taking a math test), or as one which involved others in the central experience (Social, e.g. another recount of taking a math test that included a memory of how excited the child's mother was when she received a good grade on it).

Only Social narratives were coded for the following content categories:

II. Affiliation: Statements about the state of relationships, as cast in a negative or positive tone. Talk reflecting a disturbance in unity, a dislike of another, or acts such as ignoring someone which do not promote cohesion in relationships was coded as negative affiliation ('we were fighting all summer', 'we didn't care about her'). Sentiments of good feeling towards another, or the marking of relational beginnings were coded as positive affiliation ('we started playing together in first grade'). This category also included any explicit mention of 'togetherness', as 
well as team membership or concepts of aiding and helping ('we sat together at the table', 'she helped me to it'). Reparations of conflict ('we said sorry to each other') were also coded as positive affiliation.

III. Conflict: Statements about verbal and physical acts of aggression were coded. Verbal aggression was defined as teasing, taunting, or any verbal form of conflict made by self or another ('when he came around the corner I yelled "BOO!", 'they made fun of me'). Physical aggression, on the other hand, was defined as any non-spoken negative action intended to harm or scare another ('I punched him in the stomach', 'she threw her shoe at me').

These two measures reflect the ways in which social relationships are characterized. In addition, mention of other people were coded into the following categories:

IV. Specific references to 'others': The frequency of proper names mentioned, and the number of specific different relationships mentioned (mother, brother, friend, etc.).

V. Non-specific references to 'others': The frequency of references to another person which were not proper names; included pronouns (he, her, them, etc.), references to people solely by relationship terms (my Aunt, my friend), and more vague mentioning of another ('someone said it', 'that boy hurt me').

These are essentially measures of how 'peopled' children's narratives are. References to both specific and non-specific other people indicate the extent to which children are oriented towards others in relating their experiences.

VI. Emotion talk: Statements about affect ('it was fun!' or 'I was really really mad') as well as emotional behaviour ('I cried that night'). Emotions are indicative of how personally meaningful the event is to the child.

All transcripts were coded by both authors independently. Inter-rater reliabilities, as calculated by percentage agreement, were between $79 \%$ and $98 \%$ for all coding categories; disagreements were resolved through discussion.

\section{RESULTS}

The first purpose of the study was to investigate the effect of gender on the structure and content of children's autobiographical narratives. Based on previous research we hypothesized that girls would have longer, more detailed, and more complex narratives than boys' narratives. It was further predicted that girls' narrative reports would contain more social themes, particularly references to other people. ${ }^{4}$

\section{Gender analyses}

\section{Self-concept}

For the scoring of the CSVQ, Eder (1990) presents three age scales, appropriate for $3 \frac{1}{2}-, 51 / 2$ - or $7 \frac{1}{2}$-year-old children. For the present study, the $7 \frac{1}{2}$-year-old scale was used to score children's responses.

\footnotetext{
${ }^{4}$ It should be noted that separate analyses were conducted on the subset of participants from the longitudinal study in order to examine possible differences between the two groups of children. The patterns of results were essentially the same as for those discussed below.
} 
Nine dimension scores were obtained for each child. These dimension scores were calculated by tallying 'high' responses to specific items associated with each dimension of self-concept. However, different numbers of items determine each dimension score. Therefore, different dimension scores are composed of either three, four, or five items. Thus, after tallying high responses on appropriate items for each dimension, raw scores were converted to a $0-5$ scale to standardize across dimensions according to scoring criteria developed by Eder. Thus, for any dimension, scores could range from 0 to 5 , with 0 indicating a low score, and 5, a high score. Table 2 presents the overall means and standard deviations for the nine dimensions of self-concept, according to gender.

Table 2. Means (and standard deviations) for self-concept scores according to dimension and gender

\begin{tabular}{lcl}
\hline Dimension & Boys & Girls \\
\hline Achievement & $2.64(1.12)$ & $2.45(1.04)$ \\
Aggression & $1.91(1.22)$ & $1.82(1.33)$ \\
Alienation & $0.64(1.03)$ & $1.18(1.54)$ \\
Harm avoidance & $1.27(1.19)$ & $2.45(1.37)^{*}$ \\
Social closeness & $4.38(1.15)$ & $4.69(0.69)$ \\
Social potency & $2.39(1.18)$ & $2.61(0.88)$ \\
Stress reaction & $1.48(1.23)$ & $2.27(1.92)$ \\
Traditionalism & $2.36(1.29)$ & $2.09(1.22)$ \\
Well being & $2.55(1.56)$ & $3.15(1.19)$ \\
\hline
\end{tabular}

Note: Dimension scores range from 0 to 5 .

${ }^{*} p<0.05$.

As can be seen, boys and girls scored similarly across the entire scale. In general, both boys and girls scored quite high on Social Closeness, and very low on several dimensions, including Aggression, Alienation, Stress Reaction, and Harm Avoidance, indicating a very well-adjusted sample of children. A series of $t$-tests conducted on these means confirmed the similarity across gender; the only dimension with a significant gender difference was Harm Avoidance, with girls scoring about a point higher than boys, $t(20)=-2.16, p=0.04$.

\section{Narrative measures}

All means for each narrative code, by dimension and gender are reported in Tables 3 and 4 . Overall means were also obtained for each measure by collapsing across selfconcept dimensions. These are depicted in the final row for each measure.

A series of MANOVAs with dimension as within-subjects and gender as betweensubjects variables were conducted on these means in order to determine whether boys and girls were significantly different in the structure or content of their talk about the past. Results of analyses are shown in the tables.

\section{Structural analyses}

With respect to structure, Table 3 demonstrates that girls generally gave more descriptive narratives than boys, $F(1,20)=5.35, p=0.03$. In addition, girls tended to give longer narratives overall than boys, $F(1,20)=4.69, p=0.08$, and to use more 
Table 3. Mean frequencies (and standard deviations) for each narrative structure measure by dimension and gender

\begin{tabular}{|c|c|c|c|c|c|c|c|c|}
\hline \multirow[b]{2}{*}{ Dimension } & \multicolumn{2}{|c|}{ Propositions } & \multicolumn{2}{|c|}{ Story structure } & \multicolumn{2}{|c|}{ Descriptions } & \multicolumn{2}{|c|}{ Temp/causal } \\
\hline & Boys & Girls & Boys & Girls & Boys & Girls & Boys & Girls \\
\hline Achievement & $\begin{array}{l}13.18 \\
(6.23)\end{array}$ & $\begin{array}{l}14.27 \\
(8.40)\end{array}$ & $\begin{array}{c}2.18 \\
(0.87)\end{array}$ & $\begin{array}{c}2.27 \\
(0.79)\end{array}$ & $\begin{array}{c}7.27 \\
(4.03)\end{array}$ & $\begin{array}{c}7.45 \\
(5.07)\end{array}$ & $\begin{array}{c}4.82 \\
(4.36)\end{array}$ & $\begin{array}{c}6.18 \\
(3.87)\end{array}$ \\
\hline Aggression & $\begin{array}{l}11.55 \\
(7.03)\end{array}$ & $\begin{array}{l}13.09 \\
(4.06)\end{array}$ & $\begin{array}{c}2.36 \\
(0.92)\end{array}$ & $\begin{array}{c}5.55 \\
(0.52)\end{array}$ & $\begin{array}{c}3.36 \\
(3.23)\end{array}$ & $\begin{array}{c}4.73 \\
(3.58)\end{array}$ & $\begin{array}{c}2.73 \\
(2.10)\end{array}$ & $\begin{array}{c}4.18 \\
(3.40)\end{array}$ \\
\hline Alienation & $\begin{array}{l}10.27 \\
(5.42)\end{array}$ & $\begin{array}{l}15.09 \dagger \\
(8.40)\end{array}$ & $\begin{array}{c}2.18 \\
(1.17)\end{array}$ & $\begin{array}{c}2.73 \\
(0.65)\end{array}$ & $\begin{array}{c}3.36 \\
(2.77)\end{array}$ & $\begin{array}{l}9.27^{* *} \\
(5.31)\end{array}$ & $\begin{array}{c}2.91 \\
(2.39)\end{array}$ & $\begin{array}{r}6.55 \dagger \\
(6.25)\end{array}$ \\
\hline Harm avoidance & $\begin{array}{l}11.09 \\
(7.02)\end{array}$ & $\begin{array}{l}16.09 \\
(6.36)\end{array}$ & $\begin{array}{c}2.45 \\
(0.93)\end{array}$ & $\begin{array}{c}2.55 \\
(0.93)\end{array}$ & $\begin{array}{c}2.73 \\
(2.10)\end{array}$ & $\begin{array}{l}5.45 \dagger \\
(4.34)\end{array}$ & $\begin{array}{c}4.55 \\
(4.23)\end{array}$ & $\begin{array}{c}6.18 \\
(4.36)\end{array}$ \\
\hline Soc closeness & $\begin{array}{l}13.36 \\
(3.78)\end{array}$ & $\begin{array}{l}15.91 \\
(6.76)\end{array}$ & $\begin{array}{c}2.09 \\
(0.94)\end{array}$ & $\begin{array}{c}2.45 \\
(0.69)\end{array}$ & $\begin{array}{c}3.55 \\
(2.30)\end{array}$ & $\begin{array}{c}5.09 \\
(3.05)\end{array}$ & $\begin{array}{c}4.36 \\
(3.20)\end{array}$ & $\begin{array}{c}4.82 \\
(2.64)\end{array}$ \\
\hline Soc potency & $\begin{array}{l}10.27 \\
(5.85)\end{array}$ & $\begin{array}{l}13.45 \\
(8.34)\end{array}$ & $\begin{array}{c}1.91 \\
(0.83)\end{array}$ & $\begin{array}{c}2.18 \\
(0.98)\end{array}$ & $\begin{array}{l}1.45 \\
(1.70)\end{array}$ & $\begin{array}{c}5.36^{*} \\
(6.04)\end{array}$ & $\begin{array}{c}4.27 \\
(2.57)\end{array}$ & $\begin{array}{c}5.45 \\
(4.13)\end{array}$ \\
\hline Stress reaction & $\begin{array}{l}14.64 \\
(7.16)\end{array}$ & $\begin{array}{c}17.00 \\
(12.53)\end{array}$ & $\begin{array}{c}2.55 \\
(0.93)\end{array}$ & $\begin{array}{c}2.55 \\
(1.04)\end{array}$ & $\begin{array}{c}5.55 \\
(2.73)\end{array}$ & $\begin{array}{c}6.45 \\
(6.27)\end{array}$ & $\begin{array}{c}5.36 \\
(3.75)\end{array}$ & $\begin{array}{c}6.82 \\
(5.36)\end{array}$ \\
\hline Traditionalism & $\begin{array}{c}6.45 \\
(7.30)\end{array}$ & $\begin{array}{l}14.18^{* *} \\
(4.09)\end{array}$ & $\begin{array}{c}1.36 \\
(1.29)\end{array}$ & $\begin{array}{l}2.27 \dagger \\
(0.90)\end{array}$ & $\begin{array}{c}4.09 \\
(3.53)\end{array}$ & $\begin{array}{l}7.64^{*} \\
(3.20)\end{array}$ & $\begin{array}{c}2.55 \\
(3.45)\end{array}$ & $\begin{array}{c}5.27^{*} \\
(3.04)\end{array}$ \\
\hline Well being & $\begin{array}{l}10.82 \\
(4.90)\end{array}$ & $\begin{array}{l}14.36 \\
(9.19)\end{array}$ & $\begin{array}{c}2.27 \\
(0.79)\end{array}$ & $\begin{array}{c}2.55 \\
(0.69)\end{array}$ & $\begin{array}{c}6.73 \\
(2.83)\end{array}$ & $\begin{array}{c}8.00 \\
(6.89)\end{array}$ & $\begin{array}{c}3.27 \\
(2.61)\end{array}$ & $\begin{array}{c}4.45 \\
(2.91)\end{array}$ \\
\hline Means & $\begin{array}{l}11.29 \\
(3.61)\end{array}$ & $\begin{array}{l}14.83 \dagger \\
(5.37)\end{array}$ & $\begin{array}{c}2.15 \\
(0.58)\end{array}$ & $\begin{array}{c}2.45 \\
(0.36)\end{array}$ & $\begin{array}{c}4.23 \\
(1.41)\end{array}$ & $\begin{array}{c}6.61^{*} \\
(3.10)\end{array}$ & $\begin{array}{c}3.87 \\
(1.54)\end{array}$ & $\begin{array}{r}5.55 \dagger \\
(2.64)\end{array}$ \\
\hline
\end{tabular}

${ }^{* *} p<0.01 ;{ }^{*} p<0.05 ; \dagger p<0.10$.

temporal/causal terms, $F(1,20)=3.32, p=0.08$. No significant interactions were present between gender and dimension. Two interesting effects emerged from the analyses on each self-concept dimension. First, girls used more descriptives than boys on four of the nine dimensions, indicating that this gender difference is pervasive regardless of the dimension being discussed. Second gender differences emerged most strongly for the dimension of Traditionalism, with girls giving longer, more coherent, more descriptive and more temporally/causally connected narratives than boys on this dimension. This is an interesting finding, since Traditionalism is conceptualized as the degree to which a child is compliant or obedient to authority. In the narrative prompt, children were specifically asked to tell about a time when they behaved well or had good manners; girls talked in more elaborated and complex ways about such experiences than did boys.

\section{Content analyses}

The first set of content analyses were conducted to compare the overall themes of narratives given by boys and girls. For every child, the percentage of narratives which were social was calculated, and means were obtained for each gender. On average, girls reported a higher percentage of social narratives $(88 \%)$ than boys $(71 \%)$. This difference was significant, $t(20)=-2.93, p=0.01$, although it should be noted that the majority of both girls' and boys' narratives were social.

Next, a more specific series of analyses was performed on each narrative measure of content. Results are depicted in Table 4. Overall, girls' talk was more affiliative than that of boys, $F(1,20)=4.78, p=0.04$, included more emotional words and 
Table 4. Means (and standard deviations) for each narrative content measure by dimension and gender

\begin{tabular}{|c|c|c|c|c|c|c|c|c|c|c|}
\hline \multirow[b]{2}{*}{ Dimension } & \multicolumn{2}{|c|}{ Affiliation } & \multicolumn{2}{|c|}{ Conflict } & \multicolumn{2}{|c|}{ Emotion } & \multicolumn{2}{|c|}{ Specific others } & \multicolumn{2}{|c|}{ Non-specific others } \\
\hline & Boys & Girls & Boys & Girls & Boys & Girls & Boys & Girls & Boys & Girls \\
\hline Achievement & $\begin{array}{c}1.00 \\
(2.68)\end{array}$ & $\begin{array}{c}0.55 \\
(1.29)\end{array}$ & $\begin{array}{c}0.00 \\
(0.00)\end{array}$ & $\begin{array}{c}0.18 \\
(0.60)\end{array}$ & $\begin{array}{c}1.27 \\
(2.37)\end{array}$ & $\begin{array}{c}0.92 \\
(1.04)\end{array}$ & $\begin{array}{c}2.55 \\
(3.36)\end{array}$ & $\begin{array}{c}1.82 \\
(2.71)\end{array}$ & $\begin{array}{c}3.73 \\
(3.98)\end{array}$ & $\begin{array}{c}3.27 \\
(3.69)\end{array}$ \\
\hline Aggression & $\begin{array}{c}1.09 \\
(1.36)\end{array}$ & $\begin{array}{c}2.45 \\
(2.70)\end{array}$ & $\begin{array}{c}2.91 \\
(1.97)\end{array}$ & $\begin{array}{c}2.82 \\
(2.09)\end{array}$ & $\begin{array}{c}3.27 \\
(2.05)\end{array}$ & $\begin{array}{c}3.91 \\
(1.70)\end{array}$ & $\begin{array}{c}2.45 \\
(1.92)\end{array}$ & $\begin{array}{c}3.64 \\
(2.36)\end{array}$ & $\begin{array}{c}8.09 \\
(5.05)\end{array}$ & $\begin{array}{c}8.18 \\
(3.92)\end{array}$ \\
\hline Alienation & $\begin{array}{c}1.82 \\
(1.60)\end{array}$ & $\begin{array}{c}5.91^{*} \\
(5.67)\end{array}$ & $\begin{array}{c}0.18 \\
(0.60)\end{array}$ & $\begin{array}{c}1.64 \\
(3.26)\end{array}$ & $\begin{array}{c}1.45 \\
(1.92)\end{array}$ & $\begin{array}{c}3.73 \\
(5.71)\end{array}$ & $\begin{array}{c}1.00 \\
(1.18)\end{array}$ & $\begin{array}{l}6.64^{* *} \\
(5.35)\end{array}$ & $\begin{array}{c}2.64 \\
(2.06)\end{array}$ & $\begin{array}{l}10.91^{* *} \\
(8.67)\end{array}$ \\
\hline Harm avoidance & $\begin{array}{c}0.27 \\
(0.91)\end{array}$ & $\begin{array}{c}0.64 \\
(0.67)\end{array}$ & $\begin{array}{c}0.00 \\
(0.00)\end{array}$ & $\begin{array}{c}1.09 \\
(2.77)\end{array}$ & $\begin{array}{c}1.27 \\
(1.68)\end{array}$ & $\begin{array}{c}1.82 \\
(1.78)\end{array}$ & $\begin{array}{c}0.91 \\
(1.58)\end{array}$ & $\begin{array}{c}1.64 \\
(1.36)\end{array}$ & $\begin{array}{c}1.64 \\
(2.54)\end{array}$ & $\begin{array}{c}3.82 \\
(5.29)\end{array}$ \\
\hline Soc closeness & $\begin{array}{c}1.73 \\
(2.00)\end{array}$ & $\begin{array}{l}3.82 \dagger \\
(3.06)\end{array}$ & $\begin{array}{c}0.09 \\
(0.32)\end{array}$ & $\begin{array}{c}0.09 \\
(0.32)\end{array}$ & $\begin{array}{c}1.73 \\
(1.91)\end{array}$ & $\begin{array}{c}2.00 \\
(1.72)\end{array}$ & $\begin{array}{c}3.36 \\
(3.11)\end{array}$ & $\begin{array}{c}4.27 \\
(2.45)\end{array}$ & $\begin{array}{c}5.55 \\
(4.48)\end{array}$ & $\begin{array}{l}10.09 \dagger \\
(6.47)\end{array}$ \\
\hline Soc potency & $\begin{array}{c}0.63 \\
(0.92)\end{array}$ & $\begin{array}{c}0.27 \\
(0.91)\end{array}$ & $\begin{array}{c}0.00 \\
(0.00)\end{array}$ & $\begin{array}{c}0.00 \\
(0.00)\end{array}$ & $\begin{array}{c}0.09 \\
(0.30)\end{array}$ & $\begin{array}{c}0.45 \\
(0.82)\end{array}$ & $\begin{array}{c}2.27 \\
(4.71)\end{array}$ & $\begin{array}{c}3.45 \\
(2.73)\end{array}$ & $\begin{array}{c}3.55 \\
(3.39)\end{array}$ & $\begin{array}{c}6.64 \dagger \\
(4.01)\end{array}$ \\
\hline Stress reaction & $\begin{array}{c}1.64 \\
(2.06)\end{array}$ & $\begin{array}{l}1.27 \\
(1.56)\end{array}$ & $\begin{array}{c}0.00 \\
(0.00)\end{array}$ & $\begin{array}{c}0.00 \\
(0.00)\end{array}$ & $\begin{array}{c}2.91 \\
(2.43)\end{array}$ & $\begin{array}{c}3.19 \\
(3.19)\end{array}$ & $\begin{array}{c}3.82 \\
(4.17)\end{array}$ & $\begin{array}{l}3.00 \\
(2.19)\end{array}$ & $\begin{array}{c}5.82 \\
(5.51)\end{array}$ & $\begin{array}{c}12.18 \\
(11.12)\end{array}$ \\
\hline Traditionalism & $\begin{array}{c}0.64 \\
(0.92)\end{array}$ & $\begin{array}{c}2.91 \dagger \\
(3.48)\end{array}$ & $\begin{array}{c}0.00 \\
(0.00)\end{array}$ & $\begin{array}{c}0.36 \\
(0.92)\end{array}$ & $\begin{array}{c}0.27 \\
(0.65)\end{array}$ & $\begin{array}{c}2.87^{*} \\
(2.88)\end{array}$ & $\begin{array}{c}2.00 \\
(4.05)\end{array}$ & $\begin{array}{c}4.09 \\
(3.18)\end{array}$ & $\begin{array}{c}2.27 \\
(4.29)\end{array}$ & $\begin{array}{l}8.73^{* *} \\
(5.24)\end{array}$ \\
\hline Well being & $\begin{array}{l}1.09 \\
(1.09)\end{array}$ & $\begin{array}{c}1.73 \\
(1.73)\end{array}$ & $\begin{array}{c}0.36 \\
(0.92)\end{array}$ & $\begin{array}{c}0.09 \\
(0.30)\end{array}$ & $\begin{array}{c}2.64 \\
(1.80)\end{array}$ & $\begin{array}{c}4.18 \\
(2.68)\end{array}$ & $\begin{array}{c}1.18 \\
(0.98)\end{array}$ & $\begin{array}{c}3.91^{*} \\
(3.14)\end{array}$ & $\begin{array}{c}3.45 \\
(3.10)\end{array}$ & $\begin{array}{c}9.09^{*} \\
(7.85)\end{array}$ \\
\hline Means & $\begin{array}{l}1.10 \\
(0.72)\end{array}$ & $\begin{array}{c}2.17^{*} \\
(1.45)\end{array}$ & $\begin{array}{c}0.58 \\
(0.34)\end{array}$ & $\begin{array}{c}0.91 \\
(0.72)\end{array}$ & $\begin{array}{c}1.66 \\
(0.61)\end{array}$ & $\begin{array}{c}2.53^{*} \\
(1.83)\end{array}$ & $\begin{array}{c}2.17 \\
(1.97)\end{array}$ & $\begin{array}{c}3.61 \dagger \\
(1.49)\end{array}$ & $\begin{array}{c}4.21 \\
(2.17)\end{array}$ & $\begin{array}{l}7.24^{* *} \\
(3.46)\end{array}$ \\
\hline
\end{tabular}

$* * p<0.01 ;{ }^{*} p<0.05 ; \dagger p<0.10$ . 
behaviours, $F(1,20)=4.69, p=0.04$, used more non-specific references to others, $F(1,20)=12.33, p=0.002$, and also tended to make more specific references to others than boys, $F(1,20)=3.71, p=0.07$. Furthermore, several interesting interactions between gender and dimension of self-concept were found. Post-hoc analyses indicate that girls had more affiliative talk than boys for three out of the nine dimensions, Alienation, Social Closeness, and Traditionalism. Furthermore, girls tended to make more specific and non-specific references to others for five dimensions, Alienation, Social Closeness, Social Potency, Traditionalism, and Well Being. These finding support the notion that girls explicitly'people' their narratives more than do boys.

Overall, then, gender differences were observed in the structure and content of children's autobiographical narratives about the past. Girls' narratives were longer, more temporally and causally organized, and more elaborate than those of boys. Girls also focused on more affiliative aspects of experience than did boys; more of their autobiographical narratives were not only social in overall theme but contained more references to other people and to emotions.

\section{Schematicity}

A second purpose of the present study was to examine relations between specific dimensions of self-concept and narrative measures of autobiographical memory. Since a schema is associated with a strong tendency towards a certain trait or dimension of self-concept, we hypothesized that the magnitude of dimension scores might inform us about the schematicity of self-concept dimensions. Individuals were therefore assessed on each dimension of self-concept, according to how extreme their scores were. Remember that dimension subscores indicate the high positive end of the dimension. Scores of either 0 or 5 would be 'extreme' in the sense that individuals with these scores are either highly positive for the dimension or highly negative about such aspects. It was therefore hypothesized that an extreme score on the CSVQ (5, very high or 0 , very low) might indicate schematization for a domain, whereas a non-extreme or moderate score may indicate a lack of elaborated knowledge about such a domain.

For every child, separate means were calculated for dimensions with extreme scores and dimensions with moderate scores. That is, for every child, dimensions on which children scored a 0 or 5 were identified as extreme dimensions, and means were calculated for this group of narratives along each narrative measure. Likewise, for each child, dimensions with scores between 1 and 4 were summed, and a mean calculated for each narrative measure. For example, if a child scored a 5 on Achievement and Social Closeness, and a 0 on Alienation, the frequencies of propositions in narratives about each of these dimensions were added together and a mean obtained for these 'extremes' or schematic dimensions of self-concept. The frequencies of propositions in narratives about the rest of the dimensions (with scores between 1.0 and 4.0) would be summed, and a mean would be calculated, representing the mean number of propositions about aschematic dimensions of self. Table 5 presents these means for extreme (i.e. schematic) and non-extreme (i.e. aschematic) dimensions for each narrative measure. ${ }^{5}$

\footnotetext{
${ }^{5}$ Since one individual did not have any extreme dimension scores, only 21 children were included in this set of analyses.
} 
Table 5. Mean narrative structure and content measures (and standard deviations) by dimension and schematicity

\begin{tabular}{|c|c|c|c|c|}
\hline \multirow[b]{2}{*}{ Code category } & \multicolumn{2}{|c|}{ Dimension type } & \multirow[b]{2}{*}{$t$-value } & \multirow[b]{2}{*}{$p$-value } \\
\hline & Schematic & Aschematic & & \\
\hline \#Propositions/narrative & $12.67(6.16)$ & $13.60(4.79)$ & -0.93 & 0.36 \\
\hline Story structure & $2.32(0.72)$ & $2.31(0.50)$ & 0.04 & 0.97 \\
\hline Descriptors & $4.69(3.07)$ & $5.92(2.97)$ & -2.12 & 0.05 \\
\hline Temporal/causal terms & $4.32(2.78)$ & $4.98(2.38)$ & -1.29 & 0.21 \\
\hline Overall themes (\% Social) & $81.38(35.72)$ & 76.19 (18.77) & 0.63 & 0.54 \\
\hline Affiliation & $2.06(1.81)$ & $1.48(1.33)$ & 1.55 & 0.14 \\
\hline Conflict & $0.62(0.88)$ & $0.76(0.65)$ & -0.64 & 0.53 \\
\hline Emotion words & $2.25(2.00)$ & $2.03(0.90)$ & 0.54 & 0.59 \\
\hline Specific 'others' & $3.05(2.21)$ & $2.92(2.11)$ & 0.30 & 0.77 \\
\hline Non-specific 'others' & $6.76(5.69)$ & $5.65(3.19)$ & 1.10 & 0.28 \\
\hline
\end{tabular}

Upon inspection of the means for each narrative coding category, there appear to be no differences according to the schematicity of dimensions. Dimensions with an extreme self score (either a 0 or 5) appeared to be no different from dimensions on which children scored in the moderate range (1-4). Furthermore, as indicated in Table 5, analyses by repeated measures $t$-tests confirmed this lack of significance between dimension types for any coding category, save a curious one: descriptors, $t(19)=-2.12, p=0.05$. Narratives about aschematic dimensions contained more descriptors than narratives about schematic dimensions. Thus, overall schematicity of self-concept dimensions was not meaningfully related to children's autobiographical narratives. ${ }^{6}$

\section{DISCUSSION}

In this study, we explored possible relations among children's autobiographical narratives, gender and self-concept. As predicted by theoretical frameworks and empirical findings with adults, we found intriguing gender differences in the ways in which girls and boys narrated their past experiences. However, although previous research with adolescents and adults demonstrated a link between specific dimensions of self-understanding and autobiographical narratives, we did not find evidence for such relations in this study.

Notably, few gender differences emerged on the specific dimensions of selfunderstanding, as assessed by the CSVQ; girls scored higher on Harm Avoidance than did boys but there were no differences on any of the other eight dimensions. However, girls and boys differed greatly in both the structure and the content of their autobiographical narratives. Structurally, girls' narratives were longer, more temporally-causally connected and more highly embellished with descriptive detail

\footnotetext{
${ }^{6}$ Another way to conceptualize schematicity is to examine those dimensions on which children scored only at the high end (those which children endorsed as positively related to self). A second series of analyses was performed on this set of criteria but again no relation between schematicity and narrative measures was found. Finally, analyses were also conducted to explore independently the relation between schematicity and narrative measures for each gender. Results revealed no main effects.
} 
than were those of boys. In terms of content, the majority of both boys' and girls' narratives were interpersonally situated, indicating the importance of the social world in children's personal histories. But, significantly, girls were more likely to narrate an interpersonal experience than were boys. Moreover, even when placing a past experience within an interpersonal context, girls' narratives included more affiliation themes, more emotion, and more references to both specific and non-specific others than those of boys.

Before discussing these differences in more detail, some illustrative examples are provided to give a feel for how girls and boys describe their past. Both excerpts are children's responses to the Alienation prompt, 'Tell me about a time when you felt left out, all alone, or that nobody cared about you'. Note that this prompt clearly pulls for a relationally oriented narrative, and indeed, in both examples, the children give a socially contexted narrative. Still, the gender differences are apparent. In the first example, a young girl, Megan, responds to the prompt:

... Well, I have a best friend at school and her name is Christina, and she has a nice friend that I like a lot. She was just coming over for like two or three months. Her name is Camille and she is from France. And one time I felt really left out because she was only going up to Camille and not me. [(Int: Oh really?] I felt left out. [Int: What else about that?] Um, but then we tried to get her to talk to me ... and I got to play with them.

Notice that in this narrative Megan first explicitly introduces the relationships between herself and the people involved in the event. Her narrative focuses on her feeling left out because her best friend pays more attention to the new friend than to Megan, herself. Thus the theme is the loss of a valued relationship. Note also that the situation is resolved through discussion among the three girls. In contrast, Jack's response to this prompt was as follows:

My friends at school wouldn't let me play a game since there were too much people. [Int: Oh, tell me about that.] I think it was ... umm, I don't know what the game was since they wouldn't tell me and I think David, yeah, David was in it and Michael. They wouldn't let me play ... And some other people. I don't know their names though. But they wouldn't let me play since there was lots of people in it. There were about ten people and that was enough for the game.

Although Jack also begins by mentioning 'my friends' he does not provide the kind of explicit relationship information that Megan does (e.g. 'my best friend', 'she has a nice friend'). Moreover, the gist of the narrative is being left out of a game versus Megan's narrative about feeling left out of a valued social interaction. Megan also talks about repairing the breach in the relationship, whereas Jack does not. In general, many of girls' narratives focused on groups of friends either in fights, making amends, or generally just having fun together. Boys, on the other hand, talked mostly about being excluded from a game or a team, rather than a relationship.

It must be emphasized that gender differences in children's autobiographical narratives are not simply due to language skills. First of all, although a meta-analysis conducted by Hyde and Linn (1988) indicates an overall language advantage for girls, the differences are quite small. More to the point, because many of the children in this study were part of a larger longitudinal study of autobiographical memory development, we have language measures on this subset of children beginning when they were 
40 months of age. At no point during the longitudinal study were there differences between the girls and boys on measures of grammatical development, vocabulary development, or overall literacy skills (see Reese, 1995, for details). Thus the finding that girls' narratives are longer and more complex than those of boys cannot be attributed solely to better overall language skills.

Rather, these gender differences seem to be related specifically to autobiographical narratives. These differences may emerge from differential experience and engagement in reminiscing with others. During the preschool years, parents reminisce more elaborately with daughters than with sons (Reese et al., 1996). By middle childhood, girls are spending more time one-on-one with their friends, engaging in verbal interactions (Leaper, 1991; Lever, 1976). More specifically, when girls are together, they are much more likely to share experiences with each other than are boys (Tannen, 1990). Because girls are more practised at engaging in this kind of discourse it makes sense that they will also be more skilled at it (Fivush, in press).

But, intriguingly, it is not just the ability to structure accounts of the past that differs by gender; as the examples illustrate, there are substantial differences in what girls and boys choose to talk about. Girls focus on interrelations among people. By mentioning more specific people and relationships than do boys, as well as including more non-specific references to others, girls are placing their personal experiences in more interpersonal contexts. Moreover, girls are providing more emotional information about their past than are boys. Emotions are the explicit link between the outer and inner world, in that they provide information about relations and reactions between self and other (Campos et al., 1983; Fogel, 1993). By including more emotional content than do boys, girls are relating their experiences in the world with their inner experiences of what these events mean to oneself and others. In all of these ways, girls are clearly focused on the social world in relating their personal past to a greater extent than are boys.

Of course, it is possible that gender differences in autobiographical narratives reflect gender differences in the kinds of events in which boys and girls participate. That is, girls may actually have more interpersonal experiences to relate than do boys. For example, girls are encouraged to spend time close to adults, whereas boys are encouraged to play independently (Fagot and Hagen, 1991). Still, even when relating clearly interpersonal events, girls are more likely than boys to mention the other people present and to talk about the quality of the social interactions. Thus, it appears that girls' narratives about their past are more relationally oriented than are those of boys.

This pattern is consistent with theoretical work on gender suggesting that females are more interpersonally oriented and males are more individually oriented in their self-concepts and behaviours. As outlined in the introduction, arguments stemming from psychoanalytic interpretations (Chodorow, 1978; Gilligan, 1982), from social learning perspectives (Block, 1978) and from biological speculations (Ehrhardt et al., 1984; Urdry, 1994) converge on the idea that females are more biologically and culturally prepared to develop a social orientation to the world, whereas males are prepared to develop a more individual orientation. As early as 2 years of age, females are already engaging in more nurturing behaviours than are boys (Eagley, 1987), and during the preschool years, girls seem to talk more about emotions and emotional experiences than do boys (Adams et al., 1995; Dunn et al., 1987). Thus even very early in development, we see the beginnings of a more interpersonal orientation in girls 
than in boys. Part of this is clearly facilitated by the kinds of social interactions in which girls are expected to engage; for example, parents talk more overall with girls than with boys (Leaper, in press), parents talk more about emotions with girls than with boys (Dunn et al., 1987; Fivush, 1993a), and parents encourage girls to maintain harmonious relations with others more so than they do with boys (Fivush, 1993a). However, we must be cautious about drawing conclusions about causality from these studies; girls are already behaving differently than boys from the very first days of life (Davis and Emory, 1994). Thus emerging gender differences in interpersonal orientation must be a result of complex interrelations among biological and temperamental predispositions and social-cultural expectations about gender (see Golombok and Fivush, 1994, for a review and discussion).

Regardless of the ultimate explanation of these gender differences, however, the results obtained here are a strong indication that, by middle childhood, girls and boys have already developed different ways of understanding and representing their personal past. But we found little evidence that individual differences in specific dimensions of self-understanding are related to specific autobiographical narratives of these dimensions. There are several reasons why we may have failed to find relations between children's specific self-concept scores and their autobiographical narratives.

Obviously, one possibility is that at this point in development, there are no such relations to be found. Based on Erikson's (1968; see also Marcia, 1966) theory of psychosocial development, one might expect that individuals do not begin to reflect seriously on their past experiences in relation to self until they are in the throes of the adolescent identity crisis. According to Erikson, individuals develop through a series of psychosocial 'crises', during which a particular developmental issue becomes paramount. As individuals resolve each of these crises, they develop a new level of personality integration. The crisis of identity occurs in adolescence, during which individuals begin to question 'who they are'. At this developmental point, individuals begin to reflect on their values, beliefs, and goals, ultimately setting the stage for adult personality structure based either on unquestioned acceptance of parental and/or societal values or an achieved self based on one's own integration of multiple perspectives. Consistent with this theoretical approach, it may be the case that before the onset and resolution of the identity crisis, individuals do not integrate personal experiences with self-defining values and goals.

In support of this interpretation, Neimeyer and Metzler (1994) examined autobiographical memories in relation to individuals' identity status. Based on clinical interviews, adolescents were characterized as having a diffused or committed identity status, and they were then asked to recall self-congruent and self-incongruent autobiographical memories. On a subsequent self-concept interview, individuals with a diffused identity showed more change following the recall of incongruent memories than did individuals with a committed identity. This pattern suggests that individuals still in the process of forming an adult identity are also still in the process of integrating autobiographical memories and self-understanding.

However, before we accept that there are not yet any relations between autobiographical narratives and dimensions of self-understanding in middle childhood, we must consider some methodological limitations of this study that may account for the lack of findings. First, the self-concept scale used in this study is relatively new and still under development. Because of this, it is not yet clear whether these dimensions are self-defining for children this age. That is, as the scale continues to be validated, it 
is possible that different dimensions will emerge as the critical dimensions along which children define themselves. Although we were aware of some of these problems, we chose this scale because it most closely matched the type of self-concept we were interested in measuring. Most of the other available scales in the developmental literature focus on either academic self-concept or self-esteem (see Hattie, 1992, for a review). Whereas these are important aspects of self-understanding, they do not tap into the dimensions of self-construction that might be expected to translate into how autobiographical experiences will be narrated.

Related to this was our decision to use measures of narrative structure and content in this study. Based on theoretical considerations, we postulated that dimensions important to self-definition would be reflected in longer, more coherent, and more emotionally laden autobiographical memories. But previous research finding relations between autobiographical and self-concept has relied on measures such as number of memories generated, or latency to report a memory in relation to particular self-constructs (Barclay and Subramanian, 1987; Markus, 1977; Neimeyer and Rareshide, 1991). Given the lack of relations obtained in this study, it would be instructive to examine the narrative measures used here with adolescent and adult participants, as well as to use measures of frequency and latency of memories with children, to ascertain how difference measures of autobiographical memory and selfconcept are interrelated.

In summary, although we did not find evidence of relations between dimensions of self-understanding and personal memories, these data demonstrate that gender is strongly related to autobiography. Autobiographical memories are not simply cognitive representations of what happened; they are fundamentally the ways in which we understand our experiences and ourselves, and, as the data presented here demonstrate, gender is a critical filter through which we understand the world and our place in it.

\section{ACKNOWLEDGEMENTS}

Various parts of this study were presented at The International Conference on Memory in Abano Terme, Padova, Italy, July 1996, and at the Biennial Meeting of the Society for Research in Child Development, Washington, DC, April 1997. We would like to thank the children and their families who participated in this study. Grateful appreciation to Catherine Haden, April Schwarzmueller, and Patricia Boyle for assistance with data collection, and to Karen Peterman for aid in interviewing and coding phases.

\section{REFERENCES}

Adams, S., Kuebli, J., Boyle, P. and Fivush, R. (1995). Gender differences in parentchild conversations about past emotions: A longitudinal investigation. Sex Roles, 33, 309-323.

Adcock, N. V. and Ross, M. W. (1983). Early memories, early experiences and personality. Social Behavior and Personality, 11, 95-100.

Bannister, D. and Agnew, J. (1976). The child's construing of self. Nebraska Symposium on Motivation, 24, 99-125. 
Barclay, C. R. (1986). Schematization of autobiographical memory. In D. C. Rubin (Ed.), Autobiographical memory. New York: Cambridge University Press.

Barclay, C. R. and Subramanian, G. (1987). Autobiographical memories and self-schemata. Applied Cognitive Psychology, 1(3), 169-182.

Belenky, M. F., Clinchy, B. M., Goldgerger, N. R. and Tarule, J. M. (1986). Women's ways of knowing. The development of self, voice, and mind. New York: Basic Books.

Bem, S. L. (1981). Gender schema theory: a cognitive account of sex typing. Psychological Review, 88, 354-364.

Bischoping, K. (1993). Gender differences in conversation topics, 1922-1990. Sex Roles, 28 $1-18$.

Block, J. H. (1978). Another look at sex differences in the socialization behaviors of mothers and fathers. In J. A. Sherman and F. L. Denmark (Eds), The psychology of women: Future directions in research (pp. 29-87). New York: Psychological Dimensions.

Bruner, J. (1987). Life as narrative. Social Research, 54, 11-32.

Buckner, J. P. (1996). The interrelation of early self-concept and autobiographical memory. Unpublished master's thesis, Emory University, Atlanta, GA.

Campos, J. J., Barrett, K. C., Lamb, M. E., Goldsmith, H. H. and Sternberg, C. (1983). Socioemotional development. In M. M. Haith and J. J. Campos (Eds), Infancy and developmental psychobiology. In P. Mussen (Ed.), Handbook of child psychology (Vol. 2). New York: Wiley.

Chodorow, N. J. (1978). The reproduction of mothering: Psychoanalysis and the socialization of gender. Berkeley: University of California Press.

Cowan, N. and Davidson, G. (1984). Salient childhood memories. The Journal of Genetic Psychology, 145, 101-107.

Damon, W. and Hart, D. (1988). Self-understanding in childhood and adolescence. New York: Cambridge University Press.

Davis, M. and Emory, E. (1995). Sex differences in neonatal stress reactivity. Child Development, 66, 14-27.

deVries, B., Blando, J. A. and Walker, L. J. (1995). An exploratory analysis of the content and structure of the life review. In B. K. Haight and J. D. Webster (Eds), The art and science of reminiscing. Theory, research, methods, and applications (pp. 123-137). Washington, DC: Taylor \& Francis.

Dunn, J., Bretherton, I. and Munn, P. (1987). Conversations about feeling states between mothers and their young children. Developmental Psychology, 23, 132-139.

Eagley, A. (1987). Sex differences in social behavior: A social role interpretation. Hillsdale, NJ: Erlbaum.

Eder, R. A. (1989). The emergent personologist: The structure and content of $3 \frac{112-}{2}, 5^{1 / 2-}$, and 71/2-year olds' concepts of themselves and other persons. Child Development, 60, 1218-1228.

Eder, R. A. (1990). Uncovering young children's psychological selves: Individual and developmental differences. Child Development, 61, 849-863.

Eder, R. A., Gerlach, S. G. and Perlmutter, M. (1987). In search of children's selves: Development of the specific and general components of the self-concept. Child Development, 58, 1044-1050.

Ehrhardt, A. A., Meyer-Bahlberg, H. F. L., Feldman, J. F. and Ince, S. E. (1984). Sexdimorphic behavior in childhood subsequent to prenatal exposure to exogenous progestogens and estrogens. Archives of Sexual Behavior, 13, 457-477.

Erikson, E. (1968). Youth identity and crises. New York: Norton.

Fagot, B. I. and Hagen, R. (1991). Observations of parent reactions to toddler children. Child Development, 62, 617-628.

Fitzgerald, J. M. and Lawrence, R. (1984). Autobiographical memory across the life span. Journal of Gerontology, 39, 692-698.

Fivush, R. (in press). Interest, gender, and personal narrative: How children construct selfunderstanding. In A. Karp, A. Renninger, J. Baumeister and L. Hoffman (Eds), Interest and gender in education.

Fivush, R. (1993a). Emotional content of parent-child conversations about the past. In C. A. Nelson (Ed.), The Minnesota Symposia on Child Psychology, Volume 26: Memory and affect in development, Hillsdale, NJ: Erlbaum. 
Fivush, R. (1993b). Developmental perspectives on autobiographical recall. In G. S. Goodman and B. L. Bottoms (Eds), Child victims, child witnesses: Understanding and improving testimony (pp. 1-24). New York: Guilford Press.

Fivush, R., Haden, C. and Adam, S. (1995). Structure and coherence of preschoolers' personal narratives over time: Implications for childhood amnesia. Journal of Experimental Cognitive Psychology, 60, 32-50.

Fogel, A. (1993). Developing through relationships. Chicago: University of Chicago Press.

Friedman, A. and Pines, A. (1991). Sex differences in gender-related childhood memories. Sex Roles, 25, 25-32.

Gilligan, C. (1992). In a different voice: Psychological theory and women's development. Cambridge, MA: Harvard University Press.

Golombok, S. and Fivush, R. (1994). Gender development. New York: Cambridge University Press.

Goodman, G. S. and Clarke-Stewart, A. (1991). Suggestibility in children's testimony: Implications for child sexual abuse investigations. In J. Doris (Ed.), The suggestibility of children's recollections. Washington, DC: American Psychological Association.

Greenwald, A. G. (1980). The totalitarian ego. American Psychologist, 35, 603-618.

Harter, S. (1983). Developmental perspectives on the self-system. In M. Hetherington (Ed.), Handbook of child psychology; Vol. 4. Socialization, personality, and social development (pp. 275-386). New York: Wiley.

Harter, S. (1988). Developmental and dynamic changes in the nature of the self concept: Implications for child psychotherapy. In S. R. Shirk (Ed.), Cognitive development and child psychotherapy (pp. 119-160). New York: Plenum Press.

Hattie, J. (1992). Self-Concept. Hillsdale, NJ: Erlbaum.

Hermann, D. J., Crawford, M. and Holdsworth, M. (1992). Gender-linked differences in everyday memory performance. British Journal of Psychology, 83, 221-231.

Holmberg, D. and Veroff, J. (1991). When the honeymoon's over: Memory changes for early relationship events. Paper presented at the Third International Network for Personal Relationships, Normal/Bloomington, Illinois, May.

Huston, A. C. (1988). In S. S. Brehm (Ed.), Seeing Female: Social roles and personal lives (pp. 7-19). New York: Greenwood Press.

Hyde, J. S. and Linn, M. C. (1988). Gender differences in verbal ability: A meta-analysis. Psychological Bulletin, 104, 299-324.

Labov, W. (1982). Speech actions and reaction in personal narrative. In D. Tannen (Ed.), Analyzing discourse: text and talk (pp. 12-44). Washington, DC: Georgetown University Press.

Leahy, R. L. (1985). The development of the self: conclusions. In R. L. Leahy (Ed.), The development of the self (pp. 295-304). New York: Academic Press.

Leahy, R. L. (1988). Cognitive therapy of childhood depression: Developmental considerations. In S. R. Shirk (Ed.), Cognitive development and child psychotherapy (pp. 187-204). New York: Plenum Press.

Leahy, R. L. and Shirk, S. R. (1985). Social cognition and the development of the self. In R. L. Leahy (Ed.), The development of self (pp. 123-150). Orlando, FL: Academic Press.

Leaper, C. (in press). Gender differences in parent-child talk: A meta-analysis. Developmental Psychology.

Leaper, C. (1991). Influence and involvement in children's discourse: Age, gender, and partner effects. Child Development, 62, 797-811.

Lever, J. (1976). Sex differences in the games children play. Social Problems, 23, 478-487.

Liben, L. S. and Signorella, M. L. (1980). Gender-related schemata and constructive memory in children. Child Development, 51, 11-18.

Lytton, H. and Romney, D. M. (1991). Parents' differential socialization of boys and girls: A meta-analysis. Psychological Bulletin, 109, 267-296.

Marcia, J. E. (1966). Development and validation of ego identity status. Journal of Personal and Social Psychology, 3, 551-558.

Markus, H. (1977). Self-schemata and processing information about the self. Journal of Personality and Social Psychology, 35, 63-78. 
Markus, H. (1982). Self-schemata and processing information about the self. In M. Rosenberg and H. B. Kaplan (Eds), Social psychology of the self-concept (pp. 50-66). Arlington Heights, IL: Harlan Davidson, Inc.

Markus, H. (1983). Self Knowledge: An expanded view. Journal of Personality, 51, 543-565.

Markus, H. and Nurius, P. (1987). Possible selves: The interface between maturation and the self-concept. In K. Yardley and T. Honess (Eds), Self and identity: Psychological perspectives (pp. 157-172). Chichester: Wiley.

Markus, H. and Oyserman, D. (1989). Gender and thought: The role of the self-concept. In M. Crawford and M. Gentry (Eds), Gender and thought: Psychological perspectives. New York: Springer-Verlag.

Martin, C. L. and Halverson, C. F. (1983). The effects of sex-typing on young children's memory. Child Development, 54, 563-574.

Merriam, S. B. and Cross, L. H. (1982). Adulthood and reminiscence: A descriptive study. Educational Gerontology, 8, 275-290.

Meyers-Levy, J. (1989). Gender differences in information processing: a selectivity interpretation. In P. Cafferata and A. M. Tybout (Eds), Cognitive and affective responses to advertising. Lexington, MA: Lexington Books.

Neimeyer, G. and Metzler, A. (1994). Personal identity and autobiographical recall. In U. Neisser and R. Fivush (Eds), The remembering self (pp. 105-135). New York: Cambridge University Press.

Neimeyer, G. J. and Rareshide, M. B. (1991). Personal memories and personal identity: The impact of ego identity development on autobiographical memory recall. Journal of Personality and Social Psychology, 60, 562-569.

Neisser, U. (1988). Five kinds of self knowledge. Philosophical Psychologymemory 1, $35-59$.

Nicolopoulou, A., Scales, B. and Weintraub, J. (1994). Gender differences and symbolic imagination in the stories of four-year-olds. In A. H. Dyson and C. Genishi (Eds), The need for story: Cultural diversity in classroom and community (pp. 102-123). Urbana, IL: National Council of Teachers of English.

Orlofsky, J. and Frank, M. (1986). Personality structure as viewed through early memories and identity status in college men and women. Journal of Personality and Social Psychology, 50, $580-586$.

Oyserman, D. and Markus, R. (1993). The sociocultural self. In J. Suls (Ed.), Psychological perspectives on the self. The self in social perspective (Vol. 4) (pp. 187-220). Hillsdale, NJ: Erlbaum.

Peterson, C. (1994). Narrative skills and social class. Canadian Journal of Education, 19, 251-269.

Reese, E. (1995). Predicting children's literacy from mother-child conversations. Cognitive Development, 10, 381-406.

Reese, E., Haden, C. and Fivush, R. (1996). Mothers, fathers, daughters, sons: Gender differences in reminiscing. Research on Language and Social Interaction, 29, 27-56.

Rogers, T. B., Kuiper, N. A. and Kirker, W. S. (1977). Self-reference and the encoding of personal information. Journal of Personality and Social Psychology, 35(9), 677-687.

Ross, M. and Holmberg, D. (1990). Recounting the past: Gender differences in the recall of events in the history of a close relationship. In M. P. Zanna and J. M. Olson (Eds), Self inference processes. Hillsdale, NJ: Erlbaum.

Schwartz, A. E. (1984). Earliest memories. Sex differences and the meaning of experience. Imagination, Cognition, and Personality, 4, 43-52.

Sehulster, J. R. (1996). Prospective and retrospective factors in the organization of autobiographical memory. Paper presented in J. R. Sehulster and D. Bruce (Chairs), Organization of autobiographical memory. Symposium conducted at the International Conference on Memory, Abano Terme, Padova, Italy, July.

Sheldon, (1990). Pickle fights: Gendered talk in preschool disputes. Discourse Processes, 13, $5-31$.

Spence, D. P. (1982). Narrative truth and historical truth. New York: Norton.

Stapley, J. C. and Haviland, J. M. (1989). Beyond depression: Gender differences in normal adolescents' emotional experiences. Sex Roles, 20, 295-308. 
Tannen, D. (1990). Gender differences in topical coherence: Creating involvement in best friends' talk. Discourse Processes, 13, 73-90.

Tannen, D. (1994). Gender and discourse. New York: Oxford University Press.

Thorne, A. (1995). Developmental truths in memories of childhood and adolescence. Journal of Personality, 63, 139-163.

Urdry, J. R. (1994). The nature of gender. Demography, 31, 561-573.

Webster, J. D. (1995). Adult age differences in reminiscence functions. In B. K. Haight and J. D. Webster (Eds), The art and science of reminiscing. Theory, research, methods, and applications (pp. 89-102). Washington, DC: Taylor \& Francis.

Yarmey, A. D. (1993). Adult age and gender differences in eyewitness recall in field settings. Journal of Applied Social Psychology, 23, 1921-1932. 